\title{
Challenges and Drawbacks in the Marketisation of Higher Education Within Neoliberalism
}

\author{
Gerardo del Cerro Santamaría \\ Correspondence: Gerardo del Cerro Santamaría, Ph.D., Dr. Soc. Sci., United States Fulbright Award Recipient; Expert \\ Committee Member, European Union. E-mail: gdelcerro@gmail.com
}

Received: December 14, 2019 Accepted: January 3, 2020 Online Published: January 7, 2020

doi:10.5539/res.v12n1p22

URL: https://doi.org/10.5539/res.v12n1p22

\begin{abstract}
This paper addresses some of the challenges and drawbacks associated to the ongoing worldwide process of marketization (neoliberalization) in higher education. Neoliberalism - the prevailing model of capitalist thinking based on the Washington Consensus - has conveyed the idea that a new educational and university model must emerge in order to meet the demands of a global productive system that is radically different from that of just a few decades ago. The overall argument put forward is that the requirements, particularly the managerial and labor force needs of a new economy - already developing within the parameters of globalization and the impact of information and communication technologies (ICTs) — cannot be adequately satisfied under the approaches and methods used by a traditional university. Neoliberalism affects the telos of higher education by redefining the very meaning of higher education. It dislocates education by commodifying its intrinsic value and emphasizing directly transferable skills and competencies. Nonmonetary values are marginalized and, with them, the nonmonetary ethos that is essential in sustaining a healthy democratic society. In this paper I will address (1) some of the problems and shortcomings in the triple-helix model of university-industry-government collaborations, (2) the transformation of students into customers and faculty into entrepreneurial workers, highlighting the many drawbacks of such strategies, (3) the hegemony of rankings as procedures of surveillance and control, (4) the many criticisms posed against neoliberalization in higher education and the possible alternatives looking to the future.
\end{abstract}

Keywords: marketisation, neoliberalism, entrepreneurial universities, triple helix model, customers, entrepreneurial workers, de-professionalization, rankings, challenges and drawbacks, alternatives to neoliberalism

\section{Introduction}

Neoliberalism represents a full-fledged attack on the conception and workings of institutions of higher education as they were conceived centuries ago. Neoliberalism is an umbrella concept that encompasses the ideologies favoring the extension of market relationships and values throughout society and not just in the economic realm. As a political strategy initiated by the administrations of

U.S. President Reagan and U.K. Prime Minister Thatcher in the 1980s, neoliberalism represents an attempt to shift the power balance between capital and labor by advancing entrepreneurialism as a social value, accountability as a control tool, and new managerialism as a regime of hegemony and domination in institutions, organizations, and the labor market.

Resistance to neoliberalism in academia is more widespread and entrenched than it seems (Lucas, 2014). The resistance is far from surprising because within higher education neoliberalism represents a combination of elements along two routes to authoritarian political control anticipated many decades ago by Aldous Huxley (in Brave New World) and George Orwell (in 1984). Orwell pointed out that tyranny would come through repression, "instigating and pushing people to obedience." On the other hand, Huxley believed that tyranny would impose itself by means of suggestion and seduction, thus making it possible for people to "love our own submission."

In the context of increasing pressure for changes in the university, the antagonism between academic and administrative cultures within higher education institutions has increased, and therefore it does not seem that universities' likely or desirable future is clearer now than it was when this issue was raised a few decades ago.

The reason for the impasse is, in part, due to the shortage of convincing ideas about what direction a university should take in a rapidly changing world that is undergoing a deep transition without a clearly discernible direction. As the philosopher of higher education, Ronald Barnett (2000, p. 23), observed, "The ideas of the university in the public domain are irremediably impoverished." For Barnett, they are "impoverished" because they are unduly 
confined to a small range of possible conceptions of a university and "irremediably" because they are proposed too often without conviction. Those ideas are just being used as a way to criticize without mercy the current state of universities or to simply offer a defense, often unconvincing, of the only supposedly valid alternative: the entrepreneurial, neoliberal university.

There is dissatisfaction and, at the same time, a lack of persuasion about changing the status quo of the pre-neoliberal university because, on the one hand, our ideas about changes in higher education focus too closely on the adoption of corporate models and pedagogical technology at all levels. On the other hand, many of those who resist innovations and changes in higher education expect perhaps a return to a golden age of the university as imagined by Wilhelm von Humboldt or John Henry Newman — something that is unlikely to happen.

It is important to reflect on the gradually increased significance of knowledge as intellectual capital since approximately the 1980s. This is perhaps the most important substantive change at the core of neoliberal developments in the 21 st century. Reconceptualizing knowledge as intellectual capital follows a strategy of political hegemony by conservative political organizations and the corporate world that has dominated world policy forums as alternative narratives criticizing capitalist ideology have been ignored or neglected. The political project of neoliberalism has the enthusiastic support of agencies such as the International Monetary Fund (IMF) and the World Bank, and it is an outcome of the Washington Consensus. This monolithic and homogenizing view of globalization and the knowledge economy and higher education model it legitimizes and promotes "has been facing sustained and increased criticism from many quarters, including mainstream economists" (Olssen \& Peters, 2007, p. 45).

Neoliberalism in higher education has been a constant force for change over the past few decades all over the world. Privatization and commercialization, as well as the growth of capitalist and corporate influence over higher education institutions, characterize neoliberal policies in higher education (Barnett, 2000; Burton-Jones, 1999; Carnoy \& Rhoten, 2002). As Barnett (2000, p. xxxi) wrote,

"In the neoliberal model, higher education is ideally integrated into the system of production and accumulation in which knowledge is reduced to its economic functions and contributes to the realization of individual economic utilities."

Many research studies on higher education have revolved around changes wrought by neoliberalism, including the academic stratification of the disciplines (Rhoades \& Slaughter, 1997), technology transfers (Slaughter \& Leslie, 1997), privatization (Edvinnson \& Malone, 1997), the rise of managerialism in higher education (Davies \& Bansel, 2007), and, particularly, the adoption of private sector practices and values (such as accountability), the vocationalization of the curriculum (Howard- Vital, 2006), corporatization (Suspitsyna, 2012), commercialization of both athletics and research in higher education (Bok, 2004), students as consumers and customers (Choo, 1998), and a global trend of increasing consumerism and corporatism inside the classroom (Olssen, 2002). Neoliberalism is also related to recent shifts in higher education funding toward the hard and applied sciences (fields close to the market) and away from the social sciences and humanities (Bok, 2004). Rhoads \& Torres (2006, p. 32) tellingly noted:

"Knowledge is now evaluated with the language of finance, and universities are measured by their efficiency in awarding degrees and certificates. Academic leaders are replaced by managers with business backgrounds, and the university shifts from an educational institution to just another business with a bottom line."

\section{Entrepreneurial Universities and Triple Helix}

With neoliberalism, universities are considered crucial partners in sustaining the economic growth of countries and regions by contributing human capital, innovations, and technological advances to society (Walter, Parboteeah, \& Walter, 2011). Therefore, there are challenges for a traditional university to accommodate its socioeconomic obligations through new entrepreneurial strategies.

A new concept has appeared to support entrepreneurship education (EE), basically in terms of an environment called an entrepreneurial university (EU), "which is conceived as one of the main economic growth and development engines" (Diaconu \& Duţu, 2015, p. 23). EE was intended to develop an entrepreneurial spirit in the mindset of students, to "sensitize them about entrepreneurship interest and entice them to create new projects" (Martin, McNally, \& Kay, 2012, p. 15).

EE has become compulsory in view of the need for business creation as an economic tool for growth and competitiveness. The entrepreneurial approach has become a foundation for all or most specialties, in both private and public institutions. The three main objectives of an entrepreneurial university's strategy are to educate, to stimulate, and to incubate. The background is defined by global and local competition and by the pressures of 
technological innovations on universities. The widespread perception is, "There is a real need to develop and implement an entrepreneurship culture throughout higher education" (Aranha \& Prado-Garcia, 2014, p. 63; see also Souitaris, Zerbinati, \& Al-Laham, 2007).

Although the EU concept emerged in the 1990s, it is "regarded as still in its infancy in developed countries and emerging in developing countries" (Almeida et al., 2016, p. 33; see also Etzkowitz, 2014). Forsman (2008) emphasized that an EU is "an organization with a flexible structure, competent leadership and management and where entrepreneurial culture is a key driving force." Cavaller (2011,

p. 54) maintained that an "EU is an evolutionary model of the traditional university." A key to this new paradigm is "research commercialization added to refurbished research and teaching functions" (Etzkowitz \& Leydesdorff, 2000, p. 45).

To achieve its goals, the EU is "designed to engage with external stakeholders, industry and government, and society at large" (Philpott, Dooley, O'Reilly, \& Lupton, 2011, p. 39). This is the so- called triple helix model, which involves academic-industry-government cooperation premised under common politics, policy, and methods, aiming at "internal transformation within each of these spheres" (Etzkowitz \& Leydesdorff, 2000, p. 21).

To be qualified as entrepreneurial, universities should develop different strategies through a thorough transformative process: "(1) the university starts to define its priorities and diversify its income sources, (2) the institution starts commercializing the intellectual property that arises from its research activities, and (3) the university takes an active role in participating in its regional innovation environment" (Etzkowitz, 2015, p. 63; see also Almeida et al., 2016).

Entrepreneurial universities are expected to adapt to environment fluctuation through "internal transformations, such as through changes in governance, management, flexibility, and leadership structure, in order to increase its flexibility, efficiency, and effectiveness" (Aranha \& Prado-García, 2014, p. 81). To do so, universities put in place more flexible structures "encompassing an entrepreneurial approach [that] becomes proactive and risk-taking when [universities are] deciding to innovate and seize opportunities, and utilizes creatively their resources to achieve objectives" (Diaconu \& Duţu, 2015, p. 45; see also Forsman, 2008).

To realize these goals, some entrepreneurial activities should be initiated within a university's environment, including "research mobilization, technological development, collaboration with industry, and changes in university policies and within university departments" (Todorovic, 2011, p. 85). Thus, a focus on deep internal transformations (policies, institutions, and culture) is key to the development of entrepreneurial universities. This explains why a major focus of the neoliberal strategy for higher education has been re-educating students in an entrepreneurial direction, including changing their widespread idealistic perceptions of societal environments and their role in society at large.

\section{Triple Helix Model: Variations and Contradictions}

The triple helix model of university/industry/government interactions (Etzkowitz \& Leydesdorff, 2000) has gained scholarly and policy attention. According to the model, the boundaries between industry, government, and higher education are becoming increasingly blurred and intertwined. As a result, an EU model is "emerging as a hybrid organization that combines the activities of industry, university, and public authorities to promote innovation" (Etzkowitz, 2014, p. 71). According to Sánchez (2011), universities naturally evolve toward an entrepreneurial model that emphasizes economic development in addition to the more traditional mandates of education and research "with the goal of improving national or regional economic outcomes as well as the university's financial advantage and that of its faculty" (Etzkowitz \& Leydesdorff, 2000, p. 313).

The need to access additional funding sources and "the active promotion of collaboration between universities and multiple triple helix partners through a range of public policies and infrastructures" motivate and explain this evolution (Aranha \& Prado-García, 2014, p. 67; see also Xue, 2012). Thus, universities are placing a higher priority on being "relevant and responsive to national, regional, and local needs, and these efforts have resulted in a progressive 'institutionalization' of third mission activities” (Xue, 2012, p. 63).

A scenario of increased competition for funding and policy decisions in favor of an entrepreneurial transformation "could therefore be seen as top-down coercive, normative, and mimetic 'isomorphic' forces acting upon universities" (Delanty, 2001, p. 85).

Some scholars have questioned the implicit universality of the "entrepreneurial university" phenomenon (Gibb, 2005) versus the idea that the model is an "inevitable, homogeneous, and 'isomorphic' development path" (Philpott et al., 2011, p. 42), Specifically, authors have highlighted the multiple tensions and contradictions that are likely to emerge between different university missions and activities and argue that "the degree and form of entrepreneurial 
transformation is likely to vary across countries and types of universities" (Slaughter \& Leslie, 1997, p. 33; see also Higgins \& Elliott, 2011; Kerr, 2001; Martin et al., 2012).

For instance, in a European university case study, Philpott et al. (2011, p. 33) observed a "lack of unified culture regarding the appropriateness of the third mission, as well as clear tensions and divides across disciplines on the meaning and type of entrepreneurial engagement." In a study of Spanish universities, Sanchez (2011, p. 72) identified "strong differences in the performance and capabilities of universities to balance teaching with the new third mission." Mars and Garrison's study (2009, p.91) of Australian universities found

differences in the way universities responded to government funding cuts and the emergence of new managerial models, with new, less academic universities adopting a greater focus on industrial relations and applied professional education, and old-established universities maintaining collegial loyalties and academic cultures despite reforms.

There seems to be a variety of combinations of triple helix activities in different national and regional contexts. Jansen, De Zande, Brinkkemper, Stam, and Varma (2015, p. 69) found that in the United Kingdom "different types of universities exhibited different degrees and types of knowledge transfer activity." While highly research-intensive universities focused "on the exploitation of IP and maximizing returns from research" (Gruber, 2014, p. 43), less research-intensive ones focused mainly "on activities related to human capital development." Kenney and Patton (2011) examined academic entrepreneurship in Italy, Germany, and China and emphasized the regional dimension of interactions. According to their results, there are differences in models of technology transfer depending on regional characteristics (Kenney and Patton, 2011, p. 61):

"While European regions are characterized by an under-representation of mechanisms for the adoption/exploitation of academic research (like spin-offs, mobility of human capital, or training programs), the Chinese region seems to put greater stress on direct valorization mechanisms."

\section{4. "Students as Customers" Is Not a Good Idea}

One of the central tenets of neoliberalism contends, "The individual is a rational optimizer and the best judge of his/her own interests and needs" (Olssen \& Peters, 2007, p. 314). Following this, Desai, Damewood, and Jones argued that, because students as consumers of professional output have needs and wants, "these should be better understood and met in order to provide an improved educational experience" (2001, p. 136). Other authors suggested that, in order to successfully implement the marketing concept and adopt a customer orientation in academia, "universities need to assess their students' perceptions of the institution's commitment to understanding and meeting their needs" (Browne, 2010, p. 58). There is literature suggesting that HEIs should start to focus on "students as customers" because, "students know best what they want to get from higher education. Thus, students should therefore be relied on to drive up quality" (Hatfield \& Taylor, 1998, p. 46).

However, the debate is polarized. Probably no professional, be it in education, medicine, or law, "has ever been willing to embrace guidance from outside groups or other structural levels, except their peers" (Olssen \& Peters, 2007, p. 45). This explains why there are many observers who claim that a student-customer orientation does not contribute to professionalism: "Treating students and recruiters as customers makes the school look like a training provider, rather than a university" (Argenti, 2000, P. 36; see also Chonko, Tanner, \& Davis, 2002; Eagle \& Brennan, 2007; Franz, 1998; Holbrook, 2005, 2007; Olssen \& Peters, 2007). There is also a claim that education is one of the areas where customer orientation "with its short-term financial benefits and negative consequences does not belong" (Emery, Kramer, \& Tian, 2002, p. 43; see also Holbrook, 2005) because of the risk that it would result in the decline, decay, and ultimately demise of academic values" (Clayson \& Haley, 2005, p. 51; see also Eagle \& Brennan, 2007; Snyder, 2007).

Hussey and Smith (2010, pp. 49-50) stated that the "customer" analogy may, in some cases, be inaccurate or inappropriate and even damaging because students "will get neither education nor qualification if they do not work sufficiently hard." According to Hussey and Smith, "a teacher or lecturer should not be likened to a salesperson who must acknowledge that the customer is always right." Franz (1998, p. 72) warned about "comparing the university to a shopping mall, where students shop around for classes and majors and where the goal of the educator is to attract, delight, and retain the student-customer." When universities decide to follow the customer-oriented logic, it will result in a situation where teachers would cater to students' wishes, "yielding to their complaints, and focusing more on the students' concerns for advancing their careers than about what they actually learn" (Holbrook, 2004, p. 68).

The use of the student-as-customer metaphor was intended to encourage academics "to engage in continuous improvement in order to enhance service encounters" (Yeo, 2008, p. 36; see also Koch \& Fisher, 1998). However, according to Gross and Hogler $(2005$, p. 32), "When institutions use the 'student-as-customer' metaphor, the 
teaching becomes less discretionary and more routine." Faculty and administrators, fearing a drop in student-influenced university rankings, "enforce a range of rules and regulations pertaining to quality control issues affecting student satisfaction" (Zell, 2001, p. 63). As a direct result, these processes "mediate the academic leaders" autonomy and expertise to ensure the students achieve the required learning outcomes" (Bexley, 2013, p. 21; see also Bolden, Petrov, \& Gosling, 2009). Ramsden, Prosser, Trigwell, and Martin (2007, p. 42) identified that teaching quality "may be moderated by the perceptions of the academic environment, which is partly determined by the academic leadership practices."

According to Zell, students "are not interested in their own intellectual pursuit; they attend universities to advance their own careers or get a pay increase, and usually expect high results for little effort" (2001, p. 47). Ramsden et al. (2007, p. 82) reported finding that students "most enjoy the teaching method from which they learn the least. Paradoxically, the quality of the product in education depends heavily on the hard work of the customer!" With the focus on meeting the needs of the students to the exclusion of other stakeholders, "staff can no longer adequately fulfill the requirements of other aspects of the academic duties" (Zell, 2001, p. 69; see also Chung \& McLarney, 2000). As a result, "quality education becomes a cause of concern if the service is entirely driven by what the students want and ultimately define" (Zell, 2001, p. 78).

According to Schwartzman (1995), universities may be acquiescing to students' requests that are unrealistic, irrelevant, or not fully developed because "the customer is always right" and warns that "this response may buy immediate satisfaction at the expense of the long-term best interests of the student and university" (p. 123). This approach provides "a short-term fix of instant gratification of consumer wants" and does not facilitate "long-term quality education, nor does it consider that students are not the only customers" (Redding, 2005, p. 152).

In an attempt to provide a quality education, the feedback mechanisms, such as students' evaluations, degree graduation rates, and graduate exit surveys, "circumvent the intended outcome" (Becket \& Brookes, 2008, p. 39; see also Delucchi \& Korgen, 2002; Delucchi \& Smith, 1997). While it is important to address the needs of the consumer, "a service can only be effectively provided if the provider is true to their purpose or mission" (Chung \& McLarney, 2000, p. 71). When a university embraces grade inflation, the assessment process "fails to provide the appropriate checks and balances in terms of ensuring that the students have achieved the requisite level of knowledge" (Baker, 1994, p. 158; see also Lanning \& Perkins, 1995). Further, the student-as-customer trend is "resulting in "truth in advertising' ligation against universities when students sue higher education institution for not receiving what was promised in their prospectus" (Scott, Coates, \& Anderson, 2008, p. 48).

Academic leadership has been undermined "by the emphasis placed on meeting student-as-customer demands" (Hartley, 1995, p. 26; see also Beatty, 2004; Dillard \& Tinker, 1996; Franz, 1998; Gross \& Hogler, 2005; Lomas, 2007; Newby, 1999; Svensson \& Wood, 2007). This, in turn, has had "a negative impact on job satisfaction and increased stress levels in the higher education work force" (Svensson \& Wood, 2007). This has become a concern for the higher education sector because longitudinal research identified that "job satisfaction for academics in universities is dropping at a significant rate" (Robbins, Judge, Millett, \& Waters-Marsh, 2008, p. 61).

\section{Faculty Turned Entrepreneurial Workers?}

Interest in measuring faculty productivity has increased over the past few decades as the costs of higher education have risen. External constituencies, such as legislators and parents, have begun to pay attention and to scrutinize the costs that could justify or explain tuition increases. The extended belief among these groups is that the increase in higher education costs has been due to higher faculty salaries, together with low teaching loads and a reduction in class sizes. Consequently, these people believe that larger class sizes, bigger faculty course loads, or both, could turn around the cost increases. Some studies have been designed to corroborate this belief and push faculty hard to change according to neoliberal ideas.

One must remember that, generally speaking, faculty members disagree to an important extent about the positive correlation seen by neoliberals between an increased workload and increased productivity. Academic "productivity" is importantly a direct function of professional development activities and quality time devoted to research. As a result of the divergence in views about productivity and how to measure it, and as a result of faculty members' concerns about their changing professional roles and activities under neoliberalism, a myth has been spread that faculty place more interest in developing their own professional goals and objectives, as opposed to cultivating the needs of the HEIs that employ them. As a consequence of this ongoing debate, "multiple attempts have been made from within and without higher education" to develop frameworks for "measuring and reporting on faculty activity in teaching, research, and service," in order to present a "rounded, accurate picture of what faculty do, and of what parents, legislators, and students pay for when they fund higher education" (Middaugh, 2000, p. 32). In the United States, the tool of choice to measure faculty productivity is the Delaware Study, designed by Michael Middaugh 
(Middaugh, 2000).

Efforts at measuring faculty "productivity" are at odds with the professionalism of academics and the outstanding contributions of many of them to society. In an important article published in the newsletter of the American Association of University Professors (January-February 2018), Evelyn Morales Vazquez and John S. Levin condemned the "symbolic violence that neoliberal values and managerial practices promote" (Morales Vazquez \& Levin, 2018, p. 35).

"This form of symbolic violence strips away authenticity in the work of professionals, resulting in what sociologist Richard Sennett refers to as the corrosion of character. Neoliberal practices have been taken for granted by faculty members, no matter their academic disciplines, career stages, or personal expectations. Some even aspire to a role as entrepreneurial subjects. These practices colonize the academic profession through the establishment and propagation of evaluation systems and metrics of accountability that recognize only the characteristics of the ideal entrepreneurial worker, and quantifiable actions such as publishing and securing grant funding. This distorted perspective of academic professionals does not consider what faculty members think about changes in their work environment; it ignores personal reflections on the academic profession and its purposes."

Morales Vazquez and Levin underscored the complex, differentiated, and multidimensional nature of academic work and academic identity, which cannot be homogenized according to managerial standards and reduced to a byproduct of managerial financial concerns, as it is viewed and imposed by neoliberal approaches and ideologies in higher education (Morales Vazquez \& Levin, 2018, p. 43).

"The strengthening of competition, managerial practices, and accountability has contributed to a growing disregard of the human dimension of the academic profession, particularly the personal histories and professional aspirations of faculty members. For example, reward systems highlight superficial competency and measurable behaviors, including numerical scores on student evaluations, impact factors of publication citations, and number of awards for research, teaching, and service. These systems define the ideal faculty member as one who is aligned with audit cultures, managerial practices, and standardized, homogenous values. This conceptualization of academic work acknowledges merely a fragment of the selves of faculty members. Such fragmentation denies the roles that personal histories or professional goals play in how faculty members experience their work and their academic identities. Our approach to academic identity counteracts fragmented subjectivity by emphasizing the role that social relationships, personal experiences, and emotions, as well as academic disciplines, professional status, and institutional contexts, play in the construction of, change to, or conflict in, academic identities."

The authors made a vigorous and necessary call for collective action against neoliberalism in higher education (Morales Vazquez \& Levin, 2018, p. 48).

"In 2015, a group of feminist Canadian and U.S. scholars published an article in ACME: An International Journal for Critical Geographies, "For Slow Scholarship," that called for resistance to the conditions of the neoliberal university through collective action; yet there are too few responses of this kind. We need more research and scholarship to inform leaders and policymakers-including faculty in positions of influence, such as department chairs and faculty senate officials - that the stakes are both personal and institutional."

Neoliberal practices in higher education may "discourage interaction between faculty and students" (Marginson \& Considine, 2000, p. 12). Maximizing the development of human capital through education at lower costs has become a priority for nations, and "one way to cut costs is by limiting the number of full-time faculty, hiring more contingent faculty, and increasing class size, particularly in low-cost fields of study" (Apple, 2000, p. 32; see also Slaughter, 2001). The increased role of commercial activities "has reduced the share of faculty time and resources devoted to students and teaching" (Anderson \& Sugarman, 1989, p. 41; see also Blumenthal, Epstein, \& Maxwell, 1986). Such policies "are leading to a devaluing of teaching and service" (Altbach, 1979, p. 21; see also Fairweather, 1996; Marginson \& Rhoades, 2002; Ross, 1992; Slaughter, 2001; Slaughter \& Leslie, 1997).

These changes to the profession are occurring despite the importance of frequent interactions between faculty and students that are essential for students' education, performance in college, and the attainment of positive results, as is well documented (Astin, 1993; Bean, 1985; Bean \& Kuh, 1984; Feldman \& Newcomb, 1969; Kuh, Schuh, Whitt, \& Associates, 1991; Pascarella, 1985; Pascarella \& Terenzini, 1991, 2005; Tinto, 1993). Using faculty self-reported data, Umbach (2007, p. 51) found that "part-time and full-time non-tenure-track faculty interact with students less 
frequently, both inside and outside of the classroom." This should be a reason for concern, particularly as student populations become more diverse "with increased enrollment of nontraditional students, including part-time, older, and first-generation students, who benefit from greater faculty attention" (Rendón, 1994, p. 21).

\section{De-Professionalization}

The institutionalization of neoliberal models in higher education institutions inserts a hierarchical mode of authority by which the market and state pressures are realized and made effective. De- professionalization of faculty is a major effect of this imposition of authority. Olsen \& Peters (2007), whom we follow in this section, argue that de-professionalization of faculty involves the following (Olssen \& Peters, 2007, p. 81).

+ A shift from collegial or democratic governance in flat structures, to hierarchical models based on dictated management specifications of job performance in principal-agent chains of command.

+ The implementation of restructuring initiatives in response to market and state demands increasing specifications by management over workloads and course content by management. Such hierarchically imposed specifications erode traditional conceptions of professional autonomy over work in relation to both teaching and research. Neoliberalism systematically deconstructs the space in terms of which professional autonomy is exercised.

+ Traditional conceptions of professionalism [that] involved an ascription of rights and powers over work in line with classical liberal notions of freedom of the individual. Market pressures increasingly encroach and redesign their traditional understandings of rights, as institutions must adapt to market trends (for example, just as individual departments and academics are being told of the necessity for acquiring external research grants, so they are also being told they must teach summer schools).

Olssen and Peters (2007, p. 112) continued:

"The essence of contractual models involves a specification, which is fundamentally at odds with the notion of professionalism. Professionalism conveys the idea of a subject-directed power based upon the liberal conceptions of rights, freedom, and autonomy. It conveys the idea of a power given to the subject, and of the subject's ability to make decisions in the workplace. No professional, whether doctor, lawyer, or teacher, has traditionally wanted to have the terms of their practice and conduct dictated by anyone else but their peers, or determined by groups or structural levers that are outside of their control. As a particular patterning of power, then, professionalism is systematically at odds with neoliberalism, for neoliberals see the professions as self- interested groups who indulge in rent-seeking behavior. In neoliberalism, the patterning of power is established on contract, which in turn is premised upon a need for compliance, monitoring, and accountability organized in a management line and established through a purchase contract based upon measurable outputs. “

There is a widespread perception that neoliberalism's impact on faculty's professionalism is highly problematic and contentious. For instance, Kezar (2004, p. 36) argued that "professionals have constructed a new form of identity more suited to managerialism," and that "managerial reforms have restructured the identity of professionals." Gamson (1997, p. 120) also argued that "we cannot assume that this is in any way an automatic or linear process, or that individuals respond in ways in which are consistent or coherent." Or, as Gumport (2000, p. 330) suggested:

"It is dangerous to draw sweeping conclusions about the replacement of the traditional bureau-professional organizational order in education by a managerial one. Rather, it is better to view the process as a dynamic one in which growing tensions between "old" and "new" are worked out within particular policy and management areas as different value systems and interests of influence."

Neoliberalism effectively alters the nature of the professional role of faculty. Faculty performance is assessed via "targets" and "performance criteria" that are increasingly adopted from the corporate world, thus limiting and diminishing the autonomy of professors, researchers, and scholars as professionals. There is no doubt that neoliberal agendas fight against "academic freedom" by means of, for example, placing increased importance on "managed research," and putting pressure to obtain "funded research," thus compromising the priorities and interests, as well as the independence, of individual faculty.

Along these lines, neoliberalism has directly attacked the overall idea of a public service ethic in education and the conception of the university as an autonomous realm, in the liberal professional sense. There is an urgent need to recover these noble ideals, though it remains unclear to what extent this will be possible. 


\section{Ranking for Control}

University rankings, where individual institutions are classified according to their scoring in a variety of indicators, have become widespread as a tool to measure performance and to homogenize the field of higher education. Rankings are an inevitable consequence of neoliberalism in higher education "as they are integral to audit and surveillance systems of regulation and control. They alter the internal culture of universities in terms of what they measure" (Sauder \& Epseland, 2009, p. 43).

Rankings enhance transparency, which is a positive trait, but given their political motivation they put pressure on higher education institutions "to change from being 'a center of learning' to being 'a business organization with productivity targets.' They are expected to transfer allegiance from the academic to the operational" (Doring, 2002, p. 140). Lynch . (2010, p. 61) correctly stated that:

"Treating change as a purely "technical matter," means that market values can be encoded in the heart of the university's operations without reflection. When universities focus on "key performance indicators" this directs attention to measured outputs rather than processes and inputs within education, including those of nurturing and caring."

Rankings induce "reactivity" that, in turn, "alters patterns of investment, intake, and outputs of higher education. Universities can and do improve or retain their ranks by excluding risk factors that would downgrade their status" (Lynch, 2013, p. 71). As rankings form public perceptions of universities, "senior administrators have to manage their ranking whether they wish to or not" (Farrell \& van der Werf, 2007, p. 45). Thus, "a range of 'gaming strategies' are deployed to advance university position in rankings" (Espeland \& Sauder, 2007,p. 61).

One of the most notable responses is the increased funding for "merit" scholarships to attract elite students (Espeland \& Sauder, 2007). "Merit scholarships work to the advantage of the already privileged applicants for a number of reasons, mostly because educational attainment is, in the first instant, highly dependent on the expenditure of resources in a competitive system" (Lynch, 2013, p. 25). Parents "can and do use private resources to the advantage of their own children in economically unequal societies" (Marsh, 2011, p. 31).

As Lynch (2013, p. 23) noted:

"As trust in professional integrity and peer regulation has been replaced by performance indicators, the quality of peer relations is also diminished. Relating through audits and appraisals enhances hierarchies and diminishes goodwill and collegiality. Rewarding staff on a measurable item-by-item performance basis also leads to a situation where personal career interests increasingly govern everyday academic life. As there are opportunities in the market for commercialized professionals and academics, internal divisions between staff in the universities are inevitable and open to exploitation by management. Academic capitalism brings highly individualized rewards to those who engage."

As mentioned earlier, one major problem with focusing on "performance measurement" is that it negatively affects the cultural life of students "as they are directed increasingly to economic self- interest and credential acquisition" (Lolich, 2011, p. 32). The noble ideals of students and staff to work for the common good and in the service of humanity by doing public service are seriously curtailed in a context "where universities operate as entrepreneurial, purely competitive, business- oriented corporations" (Elton, 2000, p. 41).

Neoliberalism, the new managerialism, and the marketization of universities trigger the merging of commerce and research. We now have a situation in many universities where the interests and values of business drive university research. To be sure, universities need to interact with different people and to deal with a variety of interests and priorities, but "the ethical principles and priorities of the business sector are not synonymous with those of a university" (Eisenberg, 1987, p.82). The danger is very real that the interests of university research can become synonymous with those of powerful agencies and individuals in the case that universities become too reliant on industry-funded research or too indebted to the business-driven agenda of the government.

Rankings imply a powerful "methodological fetishism" (Amsler \& Bolsmann, 2012, p. 292). Matters of methodology and accuracy in using specific methodologies (positivistic and quantitative) take the place of serious reflection on the nature and appropriateness of comparing essentially unique institutions. The focus is on getting the rankings correct, even if this has little value unless the context and politics of the use of rankings are considered. One could also argue that rankings benefit the wealthiest students as a tool they can use to decide where to attend (Archer et al., 2002; Clancy, 2001; Espeland \& Sauder, 2007; Karabel, 2005).

Rankings are also problematic because they are presented as purely objective measures of reality, while the fact that they obey a specific neoliberal political agenda is neglected. What Hacking (1990, pp. 1-10) termed "the avalanche 
of numbers" has "profoundly transformed what we choose to do, who we try to be, and what we think of ourselves" in higher education. Further, "assessment measures permit the easy conflation of what is with what ought to be, of what normal is in the statistical and moral sense." The perceived neutrality of statistics and quantitative procedures "deflects attention from their capacity to change the places and people that use them" (Espeland \& Sauder, 2007, p. 36). The generalized use of rankings of performance in higher education has very negative consequences. Rankings are a byproduct of a very specific political agenda in which some priorities are considered and others are left out. Thus, "rankings direct our attention into a different cognitive and normative order when evaluating higher education" (Lynch, 2013, p. 126). "Questions regarding the value, purpose, and politics of higher education and rankings get swept aside in the bid to find the best 'method' of ranking" (Lynch, 2013, p. 131). Matters regarding access, participation, social justice, and outcomes from higher education are usually disregarded in the "positivist drive to make ranking technologies more and more 'objective"” (Amsler \& Bolsmann, 2012, p. 292).

Another consequence is that public intellectual work is unavoidably devalued. Rankings do not measure the role and activities of academics as public intellectuals. They simply measure their communication activities with other academics in a limited number of elite journals by discussing work that is primarily or exclusively the output of commercially funded research.

Further, the increased overlap between private (market) and public perspectives and interests, the disregard of neoliberal universities for public intellectual work, and the disincentive of important relationships in neoliberal universities, all have as a consequence that knowledge is privatized to closed groups. As a result, the situation "forecloses the opportunity to have hypotheses tested or challenged from experiential (disinterested) standpoints outside the academy" (Lynch, 2013, p. 129).

\section{Criticism and Alternatives}

Neoliberalism affects the telos of higher education by redefining the very meaning of higher education. Neoliberalism dislocates education by commodifying its intrinsic value and emphasizing directly transferable skills and competencies. Nonmonetary values are marginalized and, with them, the nonmonetary moralism that is essential in sustaining a healthy democratic society. Neoliberalism has had far-reaching effects on higher education. Education is effectively reconfigured as business training to prepare the student as entrepreneur, society is reimagined as the labor market, and the importance of rooting oneself in a deliberative, just, and equitable community is lost in the face of rooting oneself in a competitive advantage.

Some of neoliberalism's features and their consequences for higher education can be summarized as follows:

+ Exclusive focus on entrepreneurial attitudes in terms organizational planning and priorities, as well as reward systems and promotion processes for faculty

+ Unwarranted homogenization of the field of higher education by using rankings to measure performance according to a specific political agenda and priorities that value excellence over equity

+ Reduction of "education" (a deeply cognitive, emotional, and ethical pursuit) to "training" and a focus on outcomes over a sensible account of origins, processes, and contexts

+ Exclusion of higher education from consideration as a public good in national political and economic priorities, together with the prevalence of individual rationality over collective explanations of behaviors and choices

+ Exclusion of nonmonetary aspects in the educational process, aspects that are deemed inefficient and, as a result, commercialization, consumerism, and transformation of students into customers deserving "satisfaction"

+ Increased overlap between scientific research and market priorities, and increasing dependence of research on corporate funders and their goals and objectives

+ Accountability and the artificial and misleading quantification of learning, which excludes fundamental ethical, cognitive, and emotional aspects in the educational process

+ A focus on marketable competencies in courses and programs, resulting in the inability of students to develop a sense of social and civic responsibility

+ Neglect of systemic disadvantage and prejudice, which leads to glaring social inequities and economic, social, and civil disparities between people and groups

In Neoliberalism's War on Higher Education, Henry Giroux reminded us what is at stake for institutions of higher education and the academy: "Privatization, commodification, militarization, and deregulation are the new guiding 
categories through which schools, teachers, pedagogy, and students are defined" (2014, p. 36). According to Giroux (2014, p. 6),

"This pedagogy of market-driven illiteracy has eviscerated the notion of freedom, turning it largely into the desire to consume and invest exclusively in relationships that serve only one's individual interests. Losing one's individuality is now tantamount to losing one's ability to consume. Shallow consumerism coupled with an indifference to the needs and suffering of others has produced a politics of disengagement and a culture of moral irresponsibility."

The use of business language and codes is widespread in order for faculty to "sell" themselves and their programs to deans and presidents in a constant search for funding. This is particularly true among faculty in the humanities. More and more universities have decided to find sponsors in the corporate world and among the wealthy to fund departments and to keep them open and active.

Neoliberalism has put forward the perception that disciplines like philosophy, religious studies, and theological studies may be irrelevant and unnecessary in an environment that favors entrepreneurial attitudes and behaviors.

Giroux's response was to develop critical pedagogies and to encourage faculty to reclaim their roles as public intellectuals (2014, p. 99):

"Academics have an ethical and pedagogical responsibility not only to unsettle and oppose all orthodoxies, to make problematic the commonsense assumptions that often shape students' lives and their understanding of the world, but also to energize them to come to terms with their own power as individual and social agents."

Giroux's ideas pointed in the direction of reflecting about the role of teachers and the value of the teaching profession: Teachers need to think about how they teach and why they teach. Indeed, teachers have the responsibility to educate the students ask to think and act in ways that promote good ideas for shaping the world and the betterment of humankind. The task of a teacher contains a profound ethical mandate: Raise up the youth so that it can contribute to a better world. According to Giroux (2014, passim), action is urgently needed in five areas:

1. There is a need for educators to analyze the connections between the widespread attack on government as a provider of public services and the transformation of higher education as a pawn of corporate power under neoliberalism. A society-wide discussion ought to be held about the fundamental value of education as a right for all, rather than an entitlement for those who can afford it. This is fundamentally a political discussion in which the priorities of government spending should be discussed and questioned. It is not acceptable to keep pointing to the increasing cost of tuition in higher education and rising student debt and yet to remain silent about the government monies spent on the military and the taxes not paid by corporations.

2. A critique of neoliberalism needs to include a debate about how to transform a market economy into a market society by realizing the damage that marketization has created in the West as well as the rest of the world. In this regard, academics need to form coalitions for collective action with broader social movements that aim at dismantling repressive institutions and other sources of injustice. Neoliberalism threatens higher education and it threatens democracy as well.

3. Academics, journalists, and others need to fully analyze the close relationships among the growing impoverishment of large segments of society and the rise of part-time labor with the massive inequality in wealth and income as manifestations of the neoliberal agenda at home and abroad.

4. It is a main responsibility of academics, teachers, researchers, professors, and scholars to fight for the rights of students to get a free education that is not colonized by corporate interests and is not aimed at developing entrepreneurial values and a neoliberal persona at the expense of fundamental features of individuals, human beings as members of collectivities and societies. Students need to be fully aware that a better world requires that they defend civil responsibility, social justice, and democracy. Too many young people, especially from low-income groups, have been excluded from getting a higher education and, in part, this means that they are left out of the social contract and the discourse of democracy.

5. Within higher education, a fundamental topic for discussion and opposition should be the ongoing shift in power relations between faculty and administration and managers. The trend has been toward lower representation or even the exclusion of faculty from the governing structures of HEIs. Administrators and their staffs now outnumber full-time faculty, producing two thirds of the increase in higher education costs in the past 20 years. This trend is the product of a clearly defined political agenda and results in the loss of job security and status by many faculty, who have been abandoned to the misery of impoverished wages, 
excessive classes, no health care, and few, if any, social benefits.

As Bill Readings' The University in Ruins (1996) made clear, there are good reasons to regret our departure from a "university of culture" and our arrival at a "university of excellence"; some call this transit a journey from a "rational academy" to a neoliberal and instrumental one. Massification, marketization, and managerialism are at the core of the neoliberal attack on higher education that enables education to emerge as a private good and a consumer product. Critical thinking on the current state of higher education is more necessary than ever.

There is a need to discuss and teach critical university studies, as Jeff Williams has proposed. We need to engage in far-reaching discussions about the university's literary, cultural, and social history. This would be a step in the right direction, which Ronald Barnett, for instance, in Being a University, showed as a normative stance about what the university ought to be in order to defend the common good and maintain the values that are intrinsic and essential to the education of human beings. This is not only an educational project, but also fundamentally a political one.

\section{Concluding Remarks}

One of the byproducts of neoliberalism is innovation, the call to constant change and renewal and "continuous improvement." This call for constant innovation in higher education has been made as an organizational and institutional requirement with apparently no alternatives. Constant innovation, a particular instance of the creative destruction in neoliberal capitalism, is presented as a fait accompli to which we must adapt and surrender without resistance.

The field operatives of neoliberalism in higher education are accreditation agencies (and too often the university administrations), which have so far played, at least in the United States, a mediating role between the U.S. federal government and academic institutions. Accrediting bodies have contributed, perhaps paradoxically, to preventing the complete transformation of our temples of knowledge and critical thinking into pawns of political, corporate, and financial power.

Has organizational and program innovation been adopted on U.S. campuses? Yes, to a degree. At the same time, the discourse on innovation has been vigorously transformed into a tool to promote social- scientific research on learning, pedagogical innovation, and the so-called "quality" of teaching, and to assuage, or even to neutralize, the ethos of quasi-military submission that nested in its corporate origin. Today, after almost two decades of experimentation, we can offer tangible results and some lessons on innovation to business and financial leaders and their political supporters, as follow.

First, it is not necessary to turn students into "customers" in order to demonstrate that they are the focus of attention in the educational process, let alone to improve their education. The students-as- customers view is stimulated by the corporate process of "customer-oriented innovation," which dictates that the interaction with the customer (in sales, marketing, service, and delivery) must be guided by satisfaction at all costs. In higher education, this idea is counterproductive or inapplicable. When applied, it has often led to harmful consequences for students, who enter the university expecting the "satisfaction" of, for example, receiving a high grade on an exam even if it is obvious that they do not deserve it.

It has been argued that the individual criteria of teachers when judging the work of a student may be in some cases questionable or arbitrary. In order to avoid this possible shortcoming, there are widespread procedures that include collective and multiple assessments that use multiple methods and external evaluators. What an educator should not do is prioritize "satisfying" students, because this would undermine the principle of quality and the spirit of sacrifice that should govern all human action in general and any educational action in particular.

Second, long before the corporate and financial world began to speak of "product innovation," educators and researchers had already embraced the Heraclitan principle of "everything flows, nothing remains." This was traditionally reflected in curricula and the contents of specific courses. Further, innovation is a form of applied creativity, and creativity and intuition have always been prominent features in the work of the best researchers in any field of knowledge - the "super-creative core" of Richard Florida - from the ancient Greeks to the present day. There are countless examples of creativity applied in the sciences, philosophy, arts, and social sciences that demonstrate the essentially dynamic nature of the search for truth and knowledge and the proclivity of researchers to constantly innovate. In this respect, the corporate world, given its fascination with innovation, could learn significantly from educators, researchers, and scholars. Third, corporate gurus like to talk about "process innovation" and to promote the idea that business organizations ought to become "communities of practice" in which the know-how of the company gets distributed in a reticular way, rather than hierarchically. Today, many corporations are new to the use of these ideas as tools to better manage their "tacit knowledge." Organizations and HEIs, think tanks, and research centers, however, have always duly respected the principle that knowledge is free and that any 
member of the organization can contribute ideas that may have an influence on the innovation of organizational processes.

In conclusion, organizational innovation in the centers of knowledge and research has, in many cases, transformed and improved the discourse and practices of continuous improvement promoted by corporate, financial, political actors, and institutions, whose original purpose was primarily to increase economic efficiency and to impose organizational and political hegemony, domination, and control.

Innovation, when it is practiced within the context of teaching, learning, and research organizations and presided over by the Aristotelian ethos of public service, is a source of examples and lessons applicable to other areas of life and society that seem much less committed to promoting the common good and more prone to indulging in self- and shareholder interests.

It is reasonable to believe that if political and corporate leaders devoted some time to reflecting about the potential benefits they would obtain by learning the approaches and methods of most teachers, scholars, and researchers, and if they acted accordingly, we would be in a position to avoid or to mitigate some of the terribly corrosive effects of power and the market that we endure today and could look into the future with greater renewed aspirations.

\section{Author Note}

The author's interest in neoliberalism and marketisation in higher education developed during his many years serving the Middle States Commission on Higher Education as a field evaluator of institutions of higher education in the United States. The insights gained through that experience are reflected in this article. This article is a substantially updated and modified version of "A Critique of Neoliberalism in Higher Education," published by Oxford University Press in 2019.

\section{References}

Adams, P. J. (2016). Moral jeopardy: Risks of accepting money from the alcohol, tobacco and gambling industries. Cambridge, U.K.: Cambridge University Press. https://doi.org/10.1017/CBO9781316118689

Almeida, M., Santos, D., Aragão, L., Nogueira, G., Bonifácio, A., Simões, B., \& Terra, B. (2016). Expanding the vision of entrepreneurial universities: A case study of UNIRIO in Brazil. Triple Helix, 5(3), 1-19. https://doi.org/10.1186/s40604-016-0033-x

Altbach, P. G. (1979). Comparative higher education: Research trends and bibliography. London, U.K.: Mansell Publishing.

Anderson, R. E., \& Sugarman, B. (1989). Options for technology transfer. Capital Ideas, 4, 1-15.

Apple, M. W. (2000). Between neoliberalism and neoconservatism: Education and conservatism in a global context. In N. C. Burbules \& C. A. Torres (Eds.), Globalization and education: Critical perspectives, 57-77. London, U.K.: Routledge.

Aranha, E. A., \& Prado, G. N. A. (2014). Dimensions of a metamodel of an entrepreneurial university. African Journal of Business Management, 8(10), 336-349.

Argenti, P. (2000). Branding B-schools: Reputation management for MBA programs. Corporate Reputation Review 3(2), 171-178. https://doi.org/10.1057/palgrave.crr.1540111

Astin, A. W. (1993). What matters in college? Four critical years revisited (1st ed.). San Francisco, CA: Jossey-Bass.

Baker, P. C. (1994). The causes and consequences of grade inflation. The Chronicle of Higher Education, 40(23), B3.

Barnett, R. (2000). Realising the university in an age of supercomplexity. Ballmoor: Open University Press.

Barnett, R. (2010). Being a university. New York, NY: Routledge. https://doi.org/10.4324/9780203842485

Bean, J. P. (1985). Interaction effects based on class level in an exploratory model of college student dropout syndrome. American Educational Research Journal, 22, 35-64. https://doi.org/10.3102/00028312022001035

Bean, J. P., \& Kuh, G. D. (1984). The reciprocity between student-faculty informal contact and the academic performance of university students. Research in Higher Education, 21(4), 461-477. https://doi.org/10.1007/BF00992637

Beatty, J. E. (2004). Grades as money and the role of the market metaphor in management education. Academy of Management Learning \& Education, 3(2), 187-196. https://doi.org/10.5465/amle.2004.13500516 
Becket, N., \& Brookes, M. (2008). Quality management practice in higher education-What quality are we actually enhancing. Journal of Hospitality, Leisure, Sport \& Tourism Education, 7(1), 40-54. https://doi.org/10.3794/johlste.71.174

Bexley, E. (2013). The motivations, values and future plans of Australian academics. Higher Education, 65(3), 385-400. https://doi.org/10.1007/s10734-012-9550-3

Blumenthal, D., Epstein, S., \& Maxwell, J. (1986). Commercializing university research: Lessons from the experience of the Wisconsin Alumni Research Foundation. New England Journal of Medicine, 31, 1621-1626. https://doi.org/10.1056/NEJM198606193142506

Bok, D. (2004). Universities in the marketplace: The commercialization of higher education. Princeton, NJ: Princeton University Press.

Bolden, R., Petrov, G., \& Gosling, J. (2009). Distributed leadership in higher education rhetoric and reality. Educational Management, Administration \& Leadership, 37(2), 257-278. https://doi.org/10.1177/1741143208100301

Browne, J. (2010). Securing a sustainable future for higher education: An independent review of higher education funding and student finance, October $12^{\text {th }}$. Retrieved from http://www.educationengland.org.uk/documents/pdfs/2010-browne-report.pdf.

Burton-Jones, A. (1999). Knowledge capitalism: Business, work and learning in the new economy. Oxford, U.K.: Oxford University Press. https://doi.org/10.1093/acprof:oso/9780198296225.001.0001

Cantwell, B., \& Kauppinen, I. (2014). Academic capitalism in the age of globalization. Baltimore, MD: Johns Hopkins University Press.

Carnoy, M., \& Rhoten, D. (2002). What does globalization mean for educational change? A comparative approach. Comparative Education Review, 46(1). https://doi.org/10.1086/324053

Cavaller, V. (2011). Portfolios for Entrepreneurship and Self-Evaluation of Higher Education Institutions, International Conference on Education and Education Psychology. Procedia Social and Behavioral Sciences, 12, 19-23. https://doi.org/10.1016/j.sbspro.2011.02.005

Chonko, L. B., Tanner, J. F., \& Davis, R. (2002). What are they thinking? Students' expectations and self-assessments. Journal of Education for Business, 77(5), 271-281. https://doi.org/10.1080/08832320209599676

Choo, C. W. (1998). The knowing organization: How organizations use information to construct meaning, create knowledge and make decisions. Oxford, U.K.: Oxford University Press.

Chung, E., \& McLarney, C. (2000). The classroom as a service encounter: Suggestions for value creation. Journal of Management Education, 24(4), 484-500. https://doi.org/10.1177/105256290002400407

Clayson, D. E., \& Haley, D. A. (2005). Marketing model in education: Students as customers, products or partners. Marketing Educational Review, 15(1), 1-10. https://doi.org/10.1080/10528008.2005.11488884

Collini, S. (2017). Speaking of universities. London: Verso.

Davies, B., \& Bansel, P. (2007). Neoliberalism and education. International Journal of Qualitative Studies in Education, 20(3), 247-259. https://doi.org/10.1080/09518390701281751

Delanty, G. (2001). Challenging knowledge: The university in the knowledge society. The Society for Research into Higher Education \& Open University Press. https://doi.org/10.1177/1350508401082002

Delucchi, M., \& Korgen, K. (2002). We're the customer-We pay the tuition: Student consumerism among undergraduate sociology majors. Teaching Sociology, 30(1), 100-107. https://doi.org/10.2307/3211524

Delucchi, M., \& Smith, W. L. (1997). A postmodern explanation of student consumerism in higher education. Teaching Sociology, 25(4), 322-327. https://doi.org/10.2307/1319301

Desai, S., Damewood, E., \& Jones, R. (2001). Be a good teacher and be seen as a good teacher. Journal of Marketing Education, 23, 136-144. https://doi.org/10.1177/0273475301232007

Diaconu, M., \& Duţu, A. (2015). The role of the modern university in supporting the entrepreneurial ecosystem. European Journal of Interdisciplinary Studies, 7(1), 11-24.

Dillard, J. F., \& Tinker, T. (1996). Commodifying business and accounting education: The implications of accreditation. Critical Perspectives on Accounting, 7(1), 215-225. https://doi.org/10.1006/cpac.1996.0027 
Docherty, T. (2018). Universities at war. London, U.K.: SAGE.

Doring, A. (2002). Challenges to the academic role of change agent. Journal of Further and Higher Education 26, 139-148. https://doi.org/10.1080/03098770220129415

Eagle, L., \& Brennan, R. (2007). Are students customers? TQM and marketing perspectives. Quality Assurance in Education, 15(1), 44-60. https://doi.org/10.1108/09684880710723025

Edvinnson, L., \& Malone, M. S. (1997). Intellectual capital. London, U.K.: Piatkus.

Eisenberg, R. S. (1987) Propriety rights and the norms of science. Yale Law Journal, 97, 177-231. https://doi.org/10.2307/796481

Elton, L. (2000). The UK research assessment exercise: Unintended consequences. Higher Educ Quart, 54, 274-283. https://doi.org/10.1111/1468-2273.00160

Emery, C., Kramer, T., \& Tian, R. (2002). Customers vs. products: Adopting an effective approach to business students. Quality Assurance in Education, 9(2), 110-115. https://doi.org/10.1108/09684880110389681

Etzkowitz, H. (2014). Making a humanities town: Knowledge-infused clusters, civic entrepreneurship and civil society in local innovation systems. Triple Helix, 2(1), 1-22. https://doi.org/10.1186/s40604-014-0012-z

Etzkowitz, H. (2015). The entrepreneurial university as a technopole platform: A global phenomenon. In J. T. Miao, P. Benneworth, \& N. A. Phelps (Eds.), Making 21st century knowledge complexes: Technopoles of the world revisited, 23-40. New York, NY: Routledge. https://doi.org/10.4324/9781315852003-2

Etzkowitz, H., \& Leydesdorff, L. (2000). The dynamics of innovation: From national systems and "mode 2" to a triple-helix of university-industry-government relations. Research Policy, 29, 109-123. https://doi.org/10.1016/S0048-7333(99)00055-4

Fairweather, J. S. (1996). Faculty work and the public trust: Restoring the value of teaching and public service in American academic life. Boston, MA: Allyn \& Bacon.

Farrell, E., \& van der Werf, M. (2007). Playing the rankings game. Chronicle of Higher Education.

Feldman, K. A., \& Newcomb, T. M. (1969). The impact of college on students (1st ed.). San Francisco, CA: Jossey-Bass.

Forsman, H. (2008). Perceptions of an Entrepreneurial University That Provides a Fertile Ground for Entrepreneurship Education. In ICSB World Conference Proceedings (p. 1). International Council for Small Business (ICSB).

Franz, R. (1998). Whatever you do, don't treat your students as customers! Journal of Management Education, 22, 63-69. https://doi.org/10.1177/105256299802200105

Gamson, Z. F. (1997). The stratification of the academy. Social Text, 51, 67-73. https://doi.org/10.2307/466647

Gibb, A. (2005). Towards the entrepreneurial university: Entrepreneurship education as a lever for change (National Council for Graduate Entrepreneurship, Policy paper \#003).

Giroux, H. (2014). Neoliberalism's war on higher education. Chicago, IL: Haymarket Books.

Gross, M. A., \& Hogler, R. (2005). What the Shadow knows: Exploring the hidden dimensions of the consumer metaphor in management education. Journal of Management Education, 29(1), 3-16. https://doi.org/10.1177/1052562903260034

Gruber, M. (2014). Marketing in new ventures: Theory and empirical evidence. Schmalenbach Business Review, 56(2), 164-199. https://doi.org/10.1007/BF03396691

Gumport, P. J. (2000). Academic restructuring: Organization change and institutional imperatives. Higher Education, 39(1), 67-91.

Hacking, I. (1990). The taming of chance. Cambridge, U.K.: Cambridge University Press. https://doi.org/10.1017/CBO9780511819766

Hartley, D. (1995). The "McDonaldization" of higher education: Food for thought? Oxford Review of Education, 21(4), 409-423. https://doi.org/10.1080/0305498950210403

Hatfield, L., \& Taylor, R. K. (1998). Making business school responsive to customers: Lessons learned and actions. Marketing Education Review, 8(2), 1-7. https://doi.org/10.1080/10528008.1998.11488627

Higgins, D., \& Elliott, C. (2011). Learning to make sense: What works in entrepreneurial education? Journal of European Industrial Training, 35(4), 345-367. https://doi.org/10.1108/03090591111128324 
Holbrook, M. B. (2004). Gratitude in graduate MBA attitudes: Re-examining the Business Week poll. Journal of Education for Business, 80(1), 25-28. https://doi.org/10.3200/JOEB.80.1.25-28

Holbrook, M. B. (2005). Marketing education as bad medicine for society: The gorilla dances. Journal of Public Policy \& Marketing, 24(1), 143-145. https://doi.org/10.1509/jppm.24.1.143.63906

Holbrook, M. B. (2007). Objective characteristics, subjective evaluations, and possible distorting biases in the business-school rankings: The case of U.S. News \& World Report.Marketing Education Review, 17(2), 1-12. https://doi.org/10.1080/10528008.2007.11488998

Howard-Vital, M. (2006). The appeal of for-profit institutions. Change: The Magazine of Higher Learning, 38(1), 68-71. https://doi.org/10.3200/CHNG.38.1.68-71

Hussey, T., \& Smith, P. (2010). The trouble with higher education: A critical examination of our universities. New York, NY: Routledge.

Huxley, A. (1932). Brave new world. New York, NY: Harper.

Jansen, S., De Zande, T. V., Brinkkemper, S., Stam, E., \& Varma, V. (2015). How education, stimulation, and incubation encourage students' entrepreneurship: Observations from MIT, IIT, and Utrecht University. The International Journal of Management Education, 13, 170-181. https://doi.org/10.1016/j.ijme.2015.03.001

Kenney, M., \& Patton, D. (2011). Does inventor ownership encourage university research-derived entrepreneurship? A six university comparison. Research Policy, 40, 1100-1112. https://doi.org/10.1016/j.respol.2011.05.012

Kerr, C. (2001). The uses of the university (5th ed.). London, U.K.: Harvard University Press.

Kezar, A. J. (2004). Obtaining integrity? Reviewing and examining the charter between higher education and society. The Review of Higher Education, 27(4), 429-459. https://doi.org/10.1353/rhe.2004.0013

Koch, J. V., \& Fisher, J. L. (1998). Higher education and total quality management. Total Quality Management, 9(8), 659-668. https://doi.org/10.1080/0954412988136

Kuh, G. D., Schuh, J. H., Whitt, E. J., \& Associates. (1991). Involving colleges. San Francisco, CA: Jossey-Bass.

Lane, J. (2012). Higher education and economic competitiveness. In Lane et al. (Eds.), Colleges and universities as economic drivers: Measuring higher education's contribution to economic development. New York: SUNY Press.

Lanning, W., \& Perkins, P. (1995). Grade inflation: A consideration of additional causes. Journal of Instructional Psychology, 22(2), 163-168.

Lolich, L. (2011). And the market created the student to its image and likening: Neo-liberal governmentality and its effects on higher education. Irish Education Studies, 30, 271-284. https://doi.org/10.1080/03323315.2011.569145

Lomas, L. (2007). Are students customers? Perceptions of academic staff. Quality in Higher Education, 13(1), 31-44. https://doi.org/10.1080/13538320701272714

Lucas, L. (2014). Academic resistance to quality assurance processes in higher education in the UK. Policy and Society, 33(3), 215-224. https://doi.org/10.1016/j.polsoc.2014.09.006

Lumpkin, G. T., \& Dess G. G. (1996). Clarifying the entrepreneurial orientation construct and linking it to performance. Academy of Management Review, 21, 135-172. https://doi.org/10.5465/amr.1996.9602161568

Lynch, K. (2010). Carelessness: A hidden doxa of higher education. Arts and Humanities in Higher Education, 9 , 54-67. https://doi.org/10.1177/1474022209350104

Lynch, K. (2013). New managerialism, neoliberalism and ranking. Ethics in Science and Environmental Politics, 13(2), 213-231. https://doi.org/10.3354/esep00137

Marginson, S., \& Considine, M. (2000). The enterprise university: Power, governance and reinvention in Australia. Cambridge, U.K.: Cambridge University Press.

Marginson, S., \& Rhoades, G. (2002). Beyond national states, markets, and systems of higher education: A glonacal agency heuristic. Higher Education, 43(3), 281-309. https://doi.org/10.1023/A:1014699605875

Mars, M. M., \& Garrison, S. (2009). Socially-oriented ventures and traditional entrepreneurship education models: A case review. Journal of Education for Business, 84, 290-296. https://doi.org/10.3200/JOEB.84.5.290-296

Marsh, J. (2011). Class dismissed: Why we cannot teach or learn our way out of inequality. New York, NY: Monthly Review Press. 
Martin, B. C., McNally, J. J., \& Kay, M. J. (2012). Examining the formation of human capital in entrepreneurship: A meta-analysis of entrepreneurship education outcomes. Journal of Business Venturing, 5(2), 1-14. https://doi.org/10.1016/j.jbusvent.2012.03.002

McGettigan, A. (2013). The great university gamble. New York: Pluto.

Middaugh, M. (2000). Understanding faculty productivity: Standards and benchmarks for colleges and universities. New York, NY: Jossey-Bass.

Morales Vazquez, E., \& Levin, J. S. (2018). The Tyranny of Neoliberalism in the American Academic Profession. AAUP Newsletter (Jan-Feb 2018). $\quad$ Retrieved from https://www.aaup.org/article/tyranny-neoliberalism-american-academic-profession\#.XXDT5y2B1uU

Newby, P. (1999). Culture and quality in higher education. Higher Education Policy, 12(3), 261-275. https://doi.org/10.1016/S0952-8733(99)00014-8

Olssen, M. (2002). The neoliberal appropriation of tertiary education policy in New Zealand: Accountability, research and academic freedom. Wellington, New Zealand: New Zealand Association for Research in Education.

Orwell, G. (1949). 1984. New York, NY: Penguin Signet Classics.

Pascarella, E. T. (1985). College environmental influences on learning and cognitive development: A critical review and synthesis. In J. C. Smart (Ed.), Higher education: Handbook of theory and research, 1, 1-62. New York, NY: Agathon.

Pascarella, E. T., \& Terenzini, P. T. (1991). How college affects students: Findings and insights from twenty years of research (1st ed.). San Francisco, CA: Jossey-Bass.

Pascarella, E. T., \& Terenzini, P. T. (2005). How college affects students: A third decade of research. San Francisco, CA: Jossey-Bass.

Philpott, K., Dooley, L., O'Reilly, C., \& Lupton, G. (2011). The entrepreneurial university: Examining the underlying academic tensions. Technovation, 31, 161-170. https://doi.org/10.1016/j.technovation.2010.12.003

Ramsden, P., Prosser, M., Trigwell, K., \& Martin, E. (2007). University teachers' experiences of academic leadership and their approaches to teaching. Learning and Instruction, 17(2), 140-155. https://doi.org/10.1016/j.learninstruc.2007.01.004

Readings, B. (1997). University in ruins. Cambridge, MA: Harvard University Press.

Redding, P. (2005). The evolving interpretations of customers in higher education: Empowering the elusive. International Journal of Consumer Studies, 29(5), 409-417. https://doi.org/10.1111/j.1470-6431.2005.00465.x

Rendón, L. I. (1994). Validating culturally diverse students: Toward a new model of learning and student development. Innovative Higher Education, 19(1), 33-51. https://doi.org/10.1007/BF01191156

Rhoades, G., \& Slaughter, S. (1997). Academic capitalism, managed professionals, and supply-side higher education. Social Text, 51, 9-38. https://doi.org/10.2307/466645

Rhoads, R. A., \& Torres, C. A. (2006). The University, State and Market. The political economy of globalization in the Americas. Stanford, CA: Stanford University Press.

Robbins, S., Judge, T., Millett, B., \& Waters-Marsh, T. (2008). Organisational behaviour (5th ed.). Frenchs Forest, NSW: Pearson Education Australia.

Ross, A. M. (1992). Two decades of Higher Education. Higher Education, 23(2), 99-112. https://doi.org/10.1007/BF00143641

Rudy, A. P. (2017). Universities in the age of corporate science: The UC Berkeley-Novartis controversy. Philadelphia, PA: Temple University Press.

Ruuska, T. (2017). Reproduction revisited: Capitalism, higher education and ecological crisis. New York: Mayfly Books.

Sánchez, J. C. (2011). University training for entrepreneurial competencies: Its impact on intention of venture creation. International Entrepreneurship Management Journal, 7, 239-254. https://doi.org/10.1007/s11365-010-0156-x

Sauder, M., \& Epseland, W. N. (2009). The discipline of rankings: Tight coupling and organizational change. American Sociological Review, 74, 63-82. https://doi.org/10.1177/000312240907400104 
Schwartzman, R. (1995). Are students customers? The metaphoric mismatch between management and education. Education, 116(2), 215-222.

Scott, G., Coates, H., \& Anderson, M. (2008). Learning leaders in times of change: Academic leadership capabilities for Australian higher education. Strawberry Hills, NSW: Australian Council for Educational Research.

Scott, P., Gallacher, J., \& Parry, G. (Eds.). (2017). New languages and landscapes of higher education. New York, NY: Oxford University Press. https://doi.org/10.1093/acprof:oso/9780198787082.001.0001

Slaughter, S. (2001). Problems in comparative higher education: Political economy, political sociology and postmodernism. Higher Education, 41(4), 389-412. https://doi.org/10.1023/A:1017505525288

Slaughter, S., \& Leslie, L. L. (1997). Academic capitalism: Politics, policies, and the entrepreneurial university. Baltimore, MD: Johns Hopkins University Press.

Snyder, E. (2007). Students as customers-Not! AACSB eNewsline, 7(1), 3-4.

Souitaris, V., Zerbinati, S., \& Al-Laham, A. (2007). Do entrepreneurship programs raise entrepreneurial intention of science and engineering students? The effect of learning, inspiration and resources. Journal of Business Venturing, 22, 566-591. https://doi.org/10.1016/j.jbusvent.2006.05.002

Suspitsyna, T. (2012). Higher education for economic advancement and engaged citizenship: An analysis of the U.S. Department of Education discourse. Journal of Higher Education, 83(1), 49-72. https://doi.org/10.1353/jhe.2012.0003

Tinto, V. (1993). Leaving college: Rethinking the causes and cures of student attrition (2nd ed.). Chicago, IL: University of Chicago Press. https://doi.org/10.7208/chicago/9780226922461.001.0001

Todorovic, Z. W., McNaughton, R. B., \& Guild, P. (2011). ENTRE-U: An entrepreneurial orientation scale for universities. Technovation, 31, 128-137. https://doi.org/10.1016/j.technovation.2010.10.009

Umbach, P. D. (2007). How effective are they? Exploring the impact of contingent faculty on undergraduate education. The Review of Higher Education, 30(2), 91-124. https://doi.org/10.1353/rhe.2006.0080

Valero, A., \& Van Reenen, J. (2016). The economic impact of universities: Evidence from across the globe, NBER, Working Paper 22501. https://doi.org/10.3386/w22501

Walter, S. G., Parboteeah, K. P., \& Walter, A. (2011). University departments and self employment intentions of business students: A cross-level analysis. Entrepreneurship Theory and Practice, 3(2), 1-26. https://doi.org/10.2139/ssrn.1953844

White House. (2013). The President's plan for a strong middle class and a strong America. Washington, DC: The White House, February 13th.

Xue, J. (2012). The construction of higher education entrepreneur services network system a research based on ecological systems theory. Physics Procedia, 25, 1757-1760. https://doi.org/10.1016/j.phpro.2012.03.307

Yeo, R. K. (2008). Brewing service quality in higher education: Characteristics of ingredients that make up the recipe. Quality Assurance in Education, 16(3), 266-286. https://doi.org/10.1108/09684880810886277

Zell, D. (2001). The market-driven business school: Has the pendulum swung too far? Journal of Management Inquiry, 10(4), 324-393. https://doi.org/10.1177/1056492601104006

\section{Copyrights}

Copyright for this article is retained by the author(s), with first publication rights granted to the journal.

This is an open-access article distributed under the terms and conditions of the Creative Commons Attribution license (http://creativecommons.org/licenses/by/4.0/). 